\title{
APPLICATION OF STEPWISE DATA ENVELOPMENT ANALYSIS AND GREY INCIDENCE ANALYSIS TO EVALUATE THE EFFECTIVENESS OF EXPORT PROMOTION PROGRAMS
}

\author{
Seyed Hossein Razavi Hajiagha ${ }^{1}$, Edmundas Kazimieras Zavadskas ${ }^{2}$, \\ Shide Sadat Hashemi ${ }^{3}$
}

\author{
${ }^{1}$ Institute for Trade Studies and Research, Tehran, Iran \\ ${ }^{2}$ Insitute of Internet and Intelligent Technologies, Vilnius Gediminas Technical University, \\ Sauletekio Ave. 11, LT-10223 Vilnius, Lithuania \\ ${ }^{3}$ Allame Tabatabaee University, Tehran, Iran \\ E-mails: ${ }^{1}$ s.hossein.r@gmail.com; ${ }^{2}$ edmundas.zavadskas@vgtu.lt (corresponding author); \\ 3shide_hashemi@yahoo.com
}

Received 14 August 2012; accepted 16 August 2012

\begin{abstract}
Export promotion programs are incentives to increase the participation of companies in international markets. On the other hand, governments try to help exporting companies with developing their goal markets. Therefore, for this purpose, many different programs have been created. To show the effectiveness of these programs, the paper refers to stepwise DEA and grey incidence analysis. Finally, the article determines a unified ranking of the applied programs that can be used by decision makers for resource allocation considering different types of programs based on their effectiveness.
\end{abstract}

Keywords: Multiple criteria decision making, stepwise DEA, grey incidence analysis, food industry, export promotion programs.

Reference to this paper should be made as follows: Razavi Hajiagha, S. H; Zavadskas, E. K; Hashemi, S. S. 2013. Application of stepwise data envelopment analysis and grey incidence analysis to evaluate the effectiveness of export promotion programs, Journal of Business Economics and Management14(3): 638-650.

JEL Classification: F14, F17, M31, C44, C51

\section{Introduction}

Economic scholars believed that export had a major and direct impact on economic conditions and growth of the country. At a micro level, the export of goods and services has become increasingly important for the survival of growth oriented domestic firms. At a macro level, exporting is important for dealing with trade deficit problems experienced by many countries (Julian, Ali 2009). These impacts persuade governments to design and provide some programs in order to promote the magnitude and diversity of export in their countries. 
Export promotion programs (EPPs) are a class of policies that governments make to encourage and reinforce domestic exporters to expand their activities. It can be defined as an incentive program designed for attracting firms into export by offering help with product and market identification and development (Korsakienė, Tvaronavičienè 2012; Travkina, Tvaronavičienè 2011; Valuckaite, Snieska 2007; Zhou et al. 2010), prescription and post-shipment, financing, training, payment guaranty schemes, trade fairs, trade visits, foreign representation, etc. (Shamsuddoha et al. 2009; Lages et al. 2008) used electronic information retrieval methods (Burinskas et al. 2010; Azimi et al. 2011; Büyüközkan 2004) and systems (Kaklauskas et al. 2002a,b, 2003, 2010; Zavadskas et al. 2005).

Some studies have shown a positive direct impact of EPPs on export performance (Balassa 1978; Kumar Roy 1993; Ramaseshan, Soutar 1996; Billings et al. 2003; Francis, Collins-Dodd 2004; Shamsuddoha, Ali 2006; Zia 2008; Julian, Ali 2009; Larbi, Chymes 2009; Lederman et al. 2010; Freixanet 2011; Argent 2011). Also, Armah and Epperson (1997), Knowles and Mathur (1997), and Onunkwo and Epperson (2000) have tried to measure the global impact of specific promotion interventions. Some studies have indirectly evaluated program effects, considering them among other factors to explain export performance (Crick, Chaudhry 1997; Katsikeas et al. 1996; Walters 1983).

This study is done to determine the effects of EPPs on Iran food industry. A set of different EPPs are proposed to food product exporters in Iran. This diversity in programs and their requested funds forces decision makers to appraise the effects of different EPPs and assign financial resources based on a logical and structured manner. The aim of this study to determine and clarify the effectiveness of EPPs in Iran is satisfied through a hybrid application of stepwise data envelopment analysis (stepwise DEA) and grey incidence analysis (GIA) methods.

The paper is organized as follows: section 2 discusses the concept of stepwise DEA, section 3 briefly introduces the GIA method and section 4 explores the framework of data gathering. The analysis and their results are presented in section 5. Finally, section 6 consists of conclusions and future work.

\section{Stepwise data envelopment analysis}

Data envelopment analysis was originally proposed by Charnes et al. (1978) as a method to evaluate the relative efficiency of a set of units that consume a set of $m$ inputs and transform them into a set of $s$ outputs. For more details on DEA refer to Cooper et al. (2002) and Ray (2004). For reviewing applications for DEA see Emrouznejad et al. (2008).

The classic CCR model can be introduced as follows. Suppose there are a set of $m$ homogenous units. Each unit, $D M U_{j}, j=1,2, \ldots, n$, use a set of $m$ inputs $X_{j}=\left(x_{1 j}, x_{2 j}, \ldots, x_{m j}\right)$ to produce a set of $s$ outputs $Y_{j}=\left(y_{1 j}, y_{2 j}, \ldots, y_{s j}\right)$. The input oriented CCR model to evaluate the relative efficiency of these DMUs for each $D M U_{0}, 0 \in\{1,2, \ldots, n\}$ is developed as follows: 


$$
\begin{aligned}
& \min \theta_{0} \\
& \sum_{j=1}^{n} \lambda_{j} x_{i j} \leq \theta_{0} x_{i 0}, i=1,2, \ldots, m, \\
& \sum_{j=1}^{n} \lambda_{j} y_{r j} \geq y_{r 0}, r=1,2, \ldots, s, \\
& \lambda_{j} \geq 0, \quad j=1,2, \ldots, n .
\end{aligned}
$$

In model (1), $\theta_{0}$ shows the radial efficiency of $D M U_{0}$ and $\lambda_{j}, j=1,2, \ldots, n$ is a vector of intensity variables. DMU is efficient if its radial efficiency is equal to one and all of its slack variables in optimal solutions of model (1) are zero. Now, suppose that the input vector is segmented into two sub vectors: discretionary inputs $X_{j}^{d}=\left(x_{1 j}^{d}, x_{2 j}^{d}, \ldots, x_{k j}^{d}\right)$ and non discretionary inputs $X_{j}^{n d}=\left(x_{1 j}^{n d}, x_{2 j}^{n d}, \ldots, x_{l j}^{n d}\right)$. Then, according to Banker and Morey (1986), the input oriented CCR model with non discretionary variables is constructed as

$$
\begin{aligned}
& \min \theta_{0} \\
& \sum_{j=1}^{n} \lambda_{j} x_{i j} \leq \theta_{0} x_{i 0}, i=1,2, \ldots, k, \\
& \sum_{j=1}^{n} \lambda_{j} x_{i j} \leq x_{i 0}, \quad i=1,2, \ldots, l, \\
& \sum_{j=1}^{n} \lambda_{j} y_{r j} \geq y_{r 0}, r=1,2, \ldots, s, \\
& \lambda_{j} \geq 0, \quad j=1,2, \ldots, n .
\end{aligned}
$$

One of the most important aspects of applying DEA is the choice of input and output variables. Golany and Roll (1989), Norman and Stocker (1991), Kittelson (1993), Lovell and Pastor (1997), Salinas-Jimenez and Smith (1996), Jenkins and Anderson (2003), Sigala et al. (2004), and Wagner and Shimshak (2007) examined this problem in the area of DEA following different procedures.

Wagner and Shimshak (2007) proposed stepwise DEA as an approach to variable selection. This method is presented in two forms: backward and forward. Since this paper uses the forward one, it is explained in this section. The forward approach has proposed some simple rules on adding variables in the DEA model - one at a time.

If a "core" model of one input and one output can be determined as a starting point, then, the stepwise method can also be adapted to add variables to the DEA model instead of dropping them. In the forward stepwise approach, the goal is the identification of variables that cause the largest difference in total efficiency scores.

Suppose there are a set of $\mathrm{m}$ inputs and s outputs to be considered for efficiency evaluation and the user wants to choose the most effective variables. As for the forward 
stepwise method, work is stated considering one input and one output as the core model. In the next step, run a set of $(m-1)+(s-1)$ DEA analysis adding one input variable and one output variable at a time in each run. Then, choose the single input or output to be added by selecting the maximum average difference in efficiency scores resulting from this single variable. The process is repeated until there are not any variables to be added or all units become efficient.

\section{Grey incidence analysis}

Deng (1982) introduced the grey system theory (GST) as a tool for studying system uncertainty. One of the major components of GST is grey incidence analysis (GIA) dealing with the analysis of complex systems consisting of multiple factors the mutual interactions of which determine the behaviour of the system. It is often the case that among all factors, investigators want to know the ones having dominant effect, whereas the others exert less influence on the development of the system (Liu, Lin 2010). GIA is applied in different studies related to system analysis, for instance, Zhou et al. (2005), Yan-hui et al. (2007), Wang et al. (2008), Lin et al. (2009) and Yue (2009). Assume that $X_{i}$ is a system factor and its observation value at ordinal position $k$ is $x_{i}(k), k=1,2, \ldots, n$. Then, $X_{i}=\left(x_{i}(1), x_{i}(2), \ldots, x_{i}(n)\right)$ is referred to as the behavioural sequence of factor $X_{i}$.

Different grey incidence degrees are defined between two behavioural sequences $X_{i}$ and $X_{0}=\left(x_{0}(1), x_{0}(2), \ldots, x_{0}(n)\right)$ as follows (Liu, Lin 2010).

Definition 1. Let $X_{i}$ and $X_{j}$ be two sequences of the same length. Then,

$$
\varepsilon_{i j}=\frac{1+\left|s_{i}\right|+\left|s_{j}\right|}{1+\left|s_{i}\right|+\left|s_{j}\right|+\left|s_{i}-s_{j}\right|},
$$

where

$$
s_{i}=\sum_{k=2}^{n-1} x_{i}^{0}(k)+\frac{1}{2} x_{i}^{0}(n)
$$

In Eq. (4), $x_{i}^{0}(k)$ is defined as $x_{i}^{0}(k)=x_{i}(k)-x_{i}(1), k=1,2, \ldots, n$ and $X_{i}^{0}$ is called the zero image of sequence $X_{i} . s_{j}$ and $s_{i}-s_{j}$ are defined similarly. Then, $\varepsilon_{i j}$ is called the absolute degree of grey incidence between $X_{i}$ and $X_{j}$.

Definition 2. Let $X_{i}$ and $X_{j}$ be two sequences of the same length with non-zero initial values. Then, $X_{i}^{\prime}$ and $X_{j}^{\prime}$ are the initial image of $X_{i}$ and $X_{j}$ obtained by dividing all elements of each sequence to its initial value, i.e.

$$
x_{i}^{\prime}(k)=\frac{x_{i}(k)}{x_{i}(1)}, k=1,2, \ldots, n .
$$

Then, the absolute degree of grey incidence of $X_{i}^{\prime}$ and $X_{j}^{\prime}$ is referred to as the relative degree of (grey) incidence of $X_{i}$ and $X_{j}$, denoted $r_{i j}$, i.e. 


$$
r_{i j}=\frac{1+\left|s_{i}^{\prime}\right|+\left|s_{j}^{\prime}\right|}{1+\left|s_{i}^{\prime}\right|+\left|s_{j}^{\prime}\right|+\left|s_{i}^{\prime}-s_{j}^{\prime}\right|},
$$

where

$$
s_{i}^{\prime}=\sum_{k=2}^{n-1} x_{i}^{\prime 0}(k)+\frac{1}{2} x_{i}^{\prime 0}(n)
$$

Definition 3. Assume that $X_{i}$ and $X_{j}$ are the sequences of the same length with nonzero initial entries. $\varepsilon_{i j}$ and $r_{i j}$ are the absolute degree and relative degree of grey incidence of $X_{i}$ and $X_{j}$, and $\theta \in[0,1]$. Then,

$$
\rho_{i j}=\theta \varepsilon_{i j}+(1-\theta) r_{i j}
$$

is called the synthetic degree of (grey) incidence between $X_{i}$ and $X_{j}$.

Note that the absolute degree looks at relationships from the angle of absolute magnitude, the relative degree - from the angle of the rates of changes in each observation with respect to their initial point and the synthetic degree - from the combined angle of both.

Now, suppose that $Y_{1}, Y_{2}, \ldots, Y_{s}$ are the sequences of the characteristic behaviour of the system (output variables), and $X_{1}, X_{2}, \ldots, X_{m}$ are the behavioural sequence of relevant factors (input variables). Then, the absolute matrix of grey incidences is the $s \times m$ matrix $A=\left[\varepsilon_{i j}\right]$, the $i j^{\text {th }}$ element of which is the absolute degree of grey incidence between $Y_{i}$ and $X_{j}$. The relative matrix of grey incidences $B=\left[r_{i j}\right]$ is the $s \times m$ matrix the $i j^{\text {th }}$ element of which is the relative degree of grey incidence between $Y_{i}$ and $X_{j}$. The synthetic matrix of grey incidences $C=\left[\rho_{i j}\right]$ is the $s \times m$ matrix the $i j^{\text {th }}$ element of which is the synthetic degree of grey incidence between $Y_{i}$ and $X_{j}$.

Considering, for example, matrix $C$, the favourability characteristics of the factors can be defined as follows:

Definition4. If $l$ and $j \in\{1,2, \ldots, m\}$ satisfy

$$
\rho_{i l} \geq \rho_{i j}
$$

for $i=1,2, \ldots, s$, then factor $X_{l}$ is supposed to be more favourable than factor $X_{j}$ denoted as $X_{l} \succ X_{j}$; if for $j=1,2, \ldots, m, j \neq l$ we always have $X_{l} \succ X_{j}$, and then $X_{l}$ is called the most favourable factor (Liu, Lin 2010).

\section{Data gathering framework}

This study was done within the period from January 2000 to December 2009. The obtained data are gathered from the existing documents and reports on export performance of food industry in Iran. The study, according to the actual reports, admits six types of EPPs along with an additional factor in the money equivalent considered as an uncontrollable factor. According to the present data, six types of EPPs can be identified: (1) export rewards (ER), (2) international exhibitions (IE), (3) protection of transfer to export (PTE), (4) currency support (CS), (5) training and announcement (TA) and (6) 
insurance support (IS). Table 1 shows data obtained considering a time period, export magnitude and money equivalent (ME).

Table 1. EPPs and export data covering the period from January 2000 to December 2009

\begin{tabular}{lllllllll}
\hline Year & Export & ER & IE & PTE & CS & TA & IS & ME \\
\hline 2000 & 207253 & 10880 & 3 & & & & 0.2 & 1750 \\
\hline 2001 & 195634 & 46658 & 3 & & & & 0 & 7950 \\
\hline 2002 & 325761 & 81309 & 4 & 620 & & & 0.3 & 8320 \\
\hline 2003 & 248755 & 65223 & 1 & 527 & & & 0.09 & 8740 \\
\hline 2004 & 4139033 & 115302 & 2 & 1115 & 68 & 73 & 0.2 & 8500 \\
\hline 2005 & 6488543 & 176641 & 3 & 1864 & 72 & 277 & 0.2 & 9000 \\
\hline 2006 & 8391825 & 217663 & 4 & 4285 & & 1221 & 0.9 & 9500 \\
\hline 2007 & 9008304 & 235806 & 3 & 2603 & 42135 & 1859 & 0.09 & 8900 \\
\hline 2008 & 11666950 & 223130 & 3 & 14955 & 4933 & 1597 & 1.4 & 9500 \\
\hline
\end{tabular}

\section{Data analysis}

This section displays the results of analyses conducted with reference to the above data.

\subsection{Stepwise DEA}

This section points to the method based on the stepwise DEA model where a classic CCR (Charnes et al. 1978) model is applied every year as a DMU. The above introduced models are performed considering ME as non-discretionary input (Banker, Moray 1986).

In a forward stepwise DEA manner, the initial efficiency of DMUs without any input is equal to zero. Now, each EPP is considered as discretionary input and that with ME as non discretionary input. The results of adding new inputs to the model are shown in Table 2.

Table 2. The results of adding one input to DEA with ME as non discretionary input

\begin{tabular}{llllllllllll}
\hline $\begin{array}{l}\text { Efficiency } \\
\text { Added } \\
\text { EPP }\end{array}$ & 2000 & 2001 & 2002 & 2003 & 2004 & 2005 & 2006 & 2007 & 2008 & 2009 & Average \\
\hline ER & 1 & 0.23 & 0.16 & 0.18 & 0.72 & 0.72 & 0.74 & 0.73 & 0.99 & 1 & 0.647 \\
\hline IE & 1 & 0.41 & 0.28 & 1 & 0.86 & 0.65 & 0.54 & 0.80 & 0.90 & 1 & 0.744 \\
\hline PTE & 1 & 1 & 0.05 & 0.02 & 1 & 0.98 & 0.56 & 1 & 0.85 & 1 & 0.746 \\
\hline CS & 1 & 1 & 1 & 1 & 0.01 & 0.01 & 1 & 0.0002 & 0.0002 & 1 & 0.602 \\
\hline TA & 1 & 1 & 1 & 1 & 1 & 0.9 & 0.32 & 0.24 & 0.40 & 1 & 0.786 \\
\hline IS & 1 & 1 & 0.3 & 0.1 & 0.24 & 0.35 & 0.1 & 1 & 1 & 1 & 0.609 \\
\hline
\end{tabular}

Since the TA variable has the highest impact on average efficiency improvement, it can be chosen in this phase as the most important EPP. In phase 2, the DEA model is 
run considering non discretionary variable $\mathrm{ME}$ and TA as two discretionary variables. Table 3 shows the received results. In this phase, PTE causes the highest increase in average efficiency and therefore this variable is chosen as the second effective EPP.

Phase 3 begins by considering non discretionary variable ME and two discretionary variables TA and EPP. The obtained efficiency is shown in Table 4 indicating that in this phase the highest increase in average efficiency is obtained by adding the ER variable.

Phase 5 runs considering ME with TA, PTE and ER. Efficiency obtained by adding the remaining EPPS is shown in Table 5 according to which the highest increase in average efficiency is achieved adding the CS variable chosen in this phase. While all DMUs reach full efficiency in this phase, adding more variables do not have any effect on efficiency.

Table 3. The results of adding one input to DEA with ME as non discretionary and TA as discretionary input

\begin{tabular}{llllllllllll}
\hline $\begin{array}{l}\text { Efficiency } \\
\begin{array}{l}\text { Added } \\
\text { EPP }\end{array}\end{array}$ & 2000 & 2001 & 2002 & 2003 & 2004 & 2005 & 2006 & 2007 & 2008 & 2009 & Average \\
\hline ER & 1 & 1 & 1 & 1 & 1 & 0.89 & 0.74 & 0.73 & 0.99 & 1 & 0.935 \\
\hline IE & 1 & 1 & 1 & 1 & 1 & 0.89 & 0.54 & 0.80 & 0.89 & 1 & 0.912 \\
\hline PTE & 1 & 1 & 1 & 1 & 1 & 1 & 0.91 & 1 & 0.85 & 1 & 0.976 \\
\hline CS & 1 & 1 & 1 & 1 & 1 & 0.89 & 1 & 0.24 & 0.39 & 1 & 0.852 \\
\hline IS & 1 & 1 & 1 & 1 & 1 & 1 & 0.68 & 1 & 1 & 1 & 0.968 \\
\hline
\end{tabular}

Table 4. The results of adding one input to DEA with ME as non discretionary and TA and PTE as discretionary inputs

\begin{tabular}{lllllllllllll}
\hline $\begin{array}{l}\text { Efficiency } \\
\begin{array}{l}\text { Added } \\
\text { EPP }\end{array}\end{array}$ & 2000 & 2001 & 2002 & 2003 & 2004 & 2005 & 2006 & 2007 & 2008 & 2009 & Average \\
\hline ER & 1 & 1 & 1 & 1 & 1 & 1 & 0.967 & 1 & 1 & 1 & 0.9967 \\
\hline IE & 1 & 1 & 1 & 1 & 1 & 1 & 0.91 & 1 & 0.96 & 1 & 0.987 \\
\hline CS & 1 & 1 & 1 & 1 & 1 & 1 & 1 & 1 & 0.966 & 1 & 0.9966 \\
\hline IS & 1 & 1 & 1 & 1 & 1 & 1 & 0.91 & 1 & 1 & 1 & 0.991 \\
\hline
\end{tabular}

Table 5. The results of adding one input to DEA with ME as non discretionary and TA, PTE and ER as discretionary inputs

\begin{tabular}{lllllllllllll}
\hline $\begin{array}{l}\text { Efficiency } \\
\text { Added EPP }\end{array}$ & 2000 & 2001 & 2002 & 2003 & 2004 & 2005 & 2006 & 2007 & 2008 & 2009 & Average \\
\hline IE & 1 & 1 & 1 & 1 & 1 & 1 & 0.96 & 1 & 1 & 1 & 0.996 \\
\hline $\mathrm{CS}$ & 1 & 1 & 1 & 1 & 1 & 1 & 1 & 1 & 1 & 1 & 1 \\
\hline IS & 1 & 1 & 1 & 1 & 1 & 1 & 0.96 & 1 & 1 & 1 & 0.996 \\
\hline
\end{tabular}

The forward stepwise DEA shows that EPPs can be ordered as follows:

$$
\mathrm{TA} \succ \mathrm{PTE} \succ \mathrm{ER} \succ \mathrm{CS} \succ \mathrm{IE}=\mathrm{IS} .
$$




\subsection{Grey incidence analysis}

In this section, data on Table 1 are analyzed employing the GIA method as described in section 3. According to Equations (3) - (8), absolute incidence matrix A, relative incidence matrix $\mathrm{B}$ and synthetic incidence matrix $\mathrm{C}$ are calculated as follows.

The results in Table 6 show that with reference to Eq. (9), the favourability of EPPs, according to their grey synthetic incidence and matrix $\mathrm{C}$, is as follows:

$$
\mathrm{ER} \succ \mathrm{CS} \succ \mathrm{PTE} \succ \mathrm{TA} \succ \mathrm{IS} \succ \mathrm{IE} .
$$

Table 6. Grey incidence matrixes

\begin{tabular}{lllllll}
\hline & ER & IE & PTE & CS & TA & IS \\
\hline A & 0.5131 & 0.500000005 & 0.50039 & 0.50053 & 0.5005 & 0.50000004 \\
\hline B & 0.500001 & 0.500000005 & 0.500002 & 0.50012 & 0.50001 & 0.50000018 \\
\hline C & 0.5065 & 0.500000005 & 0.50019 & 0.50032 & 0.500036 & 0.50000011 \\
\hline
\end{tabular}

\subsection{Aggregating the results}

Sections 5.1 and 5.2 present two distinct rankings obtained for EPPs shown in Table 7.

Table 7. EPPs ranking obtained by stepwise DEA and GIA

\begin{tabular}{ccc}
\hline \multirow{2}{*}{ EPP } & \multicolumn{2}{c}{ Ranking obtained by } \\
\cline { 2 - 3 } & Stepwise DEA & GIA \\
\hline ER & 3 & 1 \\
\hline IE & $5.5^{*}$ & 6 \\
\hline PTE & 2 & 3 \\
\hline CS & 4 & 2 \\
\hline TA & 1 & 4 \\
\hline IS & $5.5^{*}$ & 5 \\
\hline
\end{tabular}

* Since IE and IS achieved the same rank in the DEA method, this rank is obtained as the average of 5 and 6.

This section dis plays analysis carried out on the basis of the obtained results. While the achieved ranks of different EPPs are ordinal numbers, their aggregation with averaging is not appropriate. To aggregate the results of two methods, DEA and GIA, the Copeland pair-wise rank aggregation method is used (Copeland 1951; Pomerol, BarbaRomero 2000). The Copeland score is measured for element $i$ as the difference between the number of alternatives dominated by alternative $i$ based on different methods (here, DEA and GIA), minus the number of alternatives that dominate this alternative. Table 8 shows the results of the Copeland method where $M$ means that the element in the row of the table is preferred to the element in the column and $X$ shows that the element in the row is lost to or is incomparable with the element in the column. For example, the element in row 1 and column 2 of table is $M$, because ER is preferred to IE in both methods. Also, the numbers presented in the last column and row is the sum of elements 
$M$ in associated rows or columns. The final score for each element is the difference between the numbers in the row and column of this element.

Table 8. The final ranking of EPPs introducing Copeland measure

\begin{tabular}{cccccccc}
\hline & ER & IE & PTE & TA & IS & ER & $\begin{array}{c}\text { No. } \\
\text { wins }\end{array}$ \\
\hline ER & - & $\mathrm{M}$ & $\mathrm{X}$ & $\mathrm{M}$ & $\mathrm{X}$ & $\mathrm{M}$ & 3 \\
\hline IE & $\mathrm{X}$ & - & $\mathrm{X}$ & $\mathrm{X}$ & $\mathrm{X}$ & $\mathrm{X}$ & 0 \\
\hline PTE & $\mathrm{X}$ & $\mathrm{M}$ & - & $\mathrm{X}$ & $\mathrm{X}$ & $\mathrm{M}$ & 2 \\
\hline CS & $\mathrm{X}$ & $\mathrm{M}$ & $\mathrm{X}$ & - & $\mathrm{X}$ & $\mathrm{M}$ & 2 \\
\hline TA & $\mathrm{X}$ & $\mathrm{M}$ & $\mathrm{X}$ & $\mathrm{X}$ & - & $\mathrm{M}$ & 2 \\
\hline IS & $\mathrm{X}$ & $\mathrm{M}$ & $\mathrm{X}$ & $\mathrm{X}$ & $\mathrm{X}$ & - & 1 \\
\hline No. lost & 0 & 5 & 0 & 1 & 0 & 4 & \\
\hline difference & 3 & -5 & 2 & 1 & 2 & -3 & \\
\hline
\end{tabular}

Therefore, the most effective EPP is export rewards annually received by exporters. Also, the "protection of transfer to export" and "training and announcement" are in the second position. Next, currency support, insurance support and international exhibitions are in the following ranks respectfully.

\section{Conclusion}

The paper presents a hybrid application of the stepwise DEA method and grey incidence analysis to determine the effectiveness of different export promotion programs in food product industry in Iran. The conducted analysis has determined the order of different programs and specified aggregated ranking. The results shown that while some scholars believed the ineffectiveness of export rewards this condition does not hold in the considered case. To achieve a better result, these findings can help policy makers with a better assignment of limited resources of different programs. Exporters strongly prefer receiving EPPs having a great effect on their performance. It seems that direct EPPs include a direct payment to exporters in a form of export rewards have more effects and then, indirect EPPs like training and transfer have such effects. Therefore, some revisions of the value and process of export rewards might be necessary. A similar approach can be also applied to evaluating the effectiveness of any set of programs in different industries.

\section{References}

Argent, J. 2011. Price incentives to Rwanda's exporters: trade policy priorities, International Growth Centre, Rwanda Policy Note Series 2: 1-4.

Armah, B.; Epperson, J. 1997. Export demand for U.S. orange juice Impacts of U.S. export promotion programs, Agribusiness: an International Journal 13: 1-10.

Azimi, R.; Yazdani-Chamzini, A.; Fouladgar, M. M.; Zavadskas, E. K.; Basiri, M. H. 2011. Ranking the strategies of mining sector through ANP and TOPSIS in a SWOT framework, Journal of Business Economics and Management 12(4): 670-689.

http://dx.doi.org/10.3846/16111699.2011.626552 
Balassa, B. 1978. Export incentives and export performance in developing countries: a comparative analysis, Review of World Economics 114(1): 24-61.

Banker, R. D.; Morey, R. C. 1986. Efficiency analysis for exogenously fixed inputs and outputs, Operations Research 34(4): 513-521. http://dx.doi.org/10.1287/opre.34.4.513

Billings, B. A.; McGill, G. A.; Mougoué, M. 2003. The effect of export tax incentives on export volume: the DISC/FSC evidence, Advances in Taxation 15: 1-28.

http://dx.doi.org/10.1016/S1058-7497(03)15001-6

Burinskas, A.; Burinskiene, A.; Merkurjeva, G. 2010. Evaluation and comparison of selling terms in international e-commerce, European Integration Studies (4): 30-39.

Büyüközkan, G. 2004. Multi-criteria decision making for e-marketplace selection, Internet Research 14(2): 139-154. http://dx.doi.org/10.1108/10662240410530853

Charnes, A.; Cooper, W.; Rhodes, E. 1978. Measuring efficiency of decision making units, European Journal of Operational Research 2: 429-444.

http://dx.doi.org/10.1016/0377-2217(78)90138-8

Cooper, W. W.; Seiford, L. M.; Tone, K. 2002. Data envelopment analysis: a comprehensive text with models, applications, references, and DEA-solver software. New York: Kluwer Academic Publishers.

Crick, D.; Chaudhry, S. 1997. Small businesses' motives for exporting. The effect of internationalization, Journal of Marketing Practice: Applied Marketing Science 3(3): 156-170.

http://dx.doi.org/10.1108/EUM0000000004340

Copeland, A. H. 1951. A reasonable social welfare function, in Seminar on Mathematics in Social Sciences. University of Michigan.

Deng, J. L. 1982. Control problems of grey system, Systems and Control Letters 1(5): 288-294. http://dx.doi.org/10.1016/S0167-6911(82)80025-X

Emrouznejad, A.; Parkerb, B. R.; Tavaresc, G. 2008. Evaluation of research in efficiency and productivity: a survey and analysis of the first 30 years of scholarly literature in DEA, SocioEconomic Planning Sciences 42(3): 151-157. http://dx.doi.org/10.1016/j.seps.2007.07.002

Francis, J.; Collins-Dodd, C. 2004. Impact of export promotion programs on firm competencies, strategies and performance: the case of Canadian high-technology SMEs, International Marketing Review 21(4-5): 474-495. http://dx.doi.org/10.1108/02651330410547153

Freixanet, J. 2011. Export promotion programs: their impact on companies' internationalization performance and competitiveness, International Business Review 21(6): 1065-1086.

http://dx.doi.org/10.1016/j.ibusrev.2011.12.003

Golany, B.; Roll, Y. 1989. An application procedure for DEA, OMEGA 17(3): 237-250.

http://dx.doi.org/10.1016/0305-0483(89)90029-7

Jenkins, L.; Anderson, M. 2003. A multivariate statistical approach to reducing the number of variables in data envelopment analysis, European Journal of Operational Research 147(1): 5161. http://dx.doi.org/10.1016/S0377-2217(02)00243-6

Julian, C. C.; Ali, M. Y. 2009. Incentives to export for Australian export market ventures, Journal of Small Business and Enterprise Development 16(3): 418-431.

http://dx.doi.org/10.1108/14626000910977143

Kaklauskas, A.; Zavadskas, E. K.; Kaminskas, A. Z.; Trinkūnas, V.; Kaklauskienė, J. 2002a. Efficiency increase of export on-line systems by applying multiple criteria decision support systems, ICEB 2002, in Proceedings of the Second International Conference on Electronic Business "Global E-Business in Knowledge-Based Economy: Management, Practice, and Opportunities", December 10-13, 2002 Taipei, Taiwan, 45-47.

Kaklauskas, A.; Zavadskas, E. K.; Banaitis, A.; Trinkūnas, V. 2002b. Efficiency increase of export e-commerce systems by applying multiple criteria, in 9th International Multi-Conference Advanced 
Computer Systems “ACS'2002” - "SCM'2002”: Product System Design, Supply Chain Management and Logistics: Part II, proceedings. 23-25 October, 2002, Międzyzdroje, Poland, 589-597.

Kaklauskas, A.; Zavadskas, E. K.; Gikys, M.; Gulbinas, A. 2003. Multiple criteria property ebusiness system, construction innovation and global competitiveness. The organization and management of construction, vol. 1, 2, in 10th International Symposium on Construction Innovation and Global Competitiveness, 9-13 September, 2003, Ohio, 739-752.

Kaklauskas, A.; Zavadskas, E. K.; Pruskus, V.; Vlasenko, A.; Seniut, M.; Kaklauskas, G.; Matuliauskaite, A.; Gribniak, V. 2010. Biometric and intelligent self-assessment of student progress system, Computers and Education 55(2): 821-833.

http://dx.doi.org/10.1016/j.compedu.2010.03.014

Katsikeas, C.; Piercy, N.; Ioannidis, C. 1996. Determinants of export performance in a European context, European Journal of Marketing 30(6): 6-35. http://dx.doi.org/10.1108/03090569610121656

Kittelson, S. A. C. 1993. Stepwise DEA: Choosing Variables for Measuring Technical Efficiency in Norwegian Electricity Distribution. Memorandum No. 06/93, Department of Economics, University of Oslo, Norway.

Knowles, L.; Mathur, I. 1997. The effectiveness of the foreign trade zone as an export promotion program. Policy issues and alternatives, Journal of Macro Marketing 17(2): 20-31.

http://dx.doi.org/10.1177/027614679701700203

Korsakienè, R.; Tvaronavičienè, M. 2012. The internationalization of SMEs: an integrative approach, Journal of Business Economics and Management 13(2): 294-307.

http://dx.doi.org/10.3846/16111699.2011.620138

Kumar Roy, D. 1993. Impact of incentives on export performance of Bangladesh: a preliminary assessment, The Bangladesh Development Studies 21(2): 25-44.

Lages, L. F.; Jap, D. S.; Griffith, A. D. 2008. The role of past performance in export ventures: a short-term reactive approach, Journal of International Business Studies 39(2): 304-325.

http://dx.doi.org/10.1057/palgrave.jibs.8400339

Larbi, W.; Chymes, A. 2009. The impact of the government policies and incentives to promote the export of agricultural products in Tunisia: case of olive oil, Food Economics - Acta Agriculture Scandinavica 7(2-4): 17-118.

Lederman, D.; Olarreaga, M.; Payton, L. 2010. Export promotion agencies: do they work?, Journal of Development Economics 91(2): 257-265. http://dx.doi.org/10.1016/j.jdeveco.2009.09.003

Lin, W. Z.; Xiao, X.; Chou, K. C. 2009. GPCR-GIA: a web-server for identifying G-protein coupled receptors and their families with grey incidence analysis, Protein Engineering, Design and Selection 22(11): 699-705. http://dx.doi.org/10.1093/protein/gzp057

Liu, S.; Lin, Y. 2010. Grey systems theory and applications. London: Springer-Verlag.

Lovell, C. A. K.; Pastor, J. T. 1997. Target setting: an application to a bank branch network, European Journal of Operational Research 98(2): 290-299.

http://dx.doi.org/10.1016/S0377-2217(96)00348-7

Norman, M.; Stoker, B. 1991. Data envelopment analysis: the assessment of performance. Chichester, England: John Wiley and Sons.

Onunkwo, I. M.; Epperson, J. E. 2000. Export demand for U.S. pecans: impact of US export promotion programs, Agribusiness: an International Journal 16(2): 253-265.

http://dx.doi.org/10.1002/(SICI)1520-6297(200021)16:2<253::AID-AGR8>3.0.CO;2-O

Pomerol, J. C.; Barba-Romero, S. 2000. Software for discrete multicriterion decision, in Multicriterion Decision Management. USA. Springer, 271-298.

http://dx.doi.org/10.1007/978-1-4615-4459-3

Ramaseshan, B.; Soutar, G. N. 1996. Combined effects of incentives and barriers on firm's export decisions, International Business Review 5(1): 53-65.

http://dx.doi.org/10.1016/0969-5931(95)00032-1 
Ray, S. C. 2004. Data Envelopment analysis: theory and techniques for economics and operations Research. Edinburgh: Cambridge University Press.

http://dx.doi.org/10.1017/CBO9780511606731

Salinas-Jimenez, J.; Smith, P. 1996. Data envelopment analysis applied to quality in primary health care, Annals of Operations Research 67(1): 141-161. http://dx.doi.org/10.1007/BF02187027

Shamsuddoha, A. K.; Ali, M. Y. 2006. Mediated effects of export promotion programs on firm export performance, Asia Pacific Journal of Marketing and Logistic 18(2): 93-110.

http://dx.doi.org/10.1108/13555850610658255

Shamsuddoha, A. K.; Ali, Y. M.; Ndubisi, N. O. 2009. Impact of government export assistance on internationalization of SMEs from developing nations, Journal of Enterprise Information Management 22(4): 408-422. http://dx.doi.org/10.1108/17410390910975022

Sigala, M.; Airey, D.; Jones, P.; Lockwood, A. 2004. ICT paradox lost? A stepwise DEA methodology to evaluate technology investments in tourism settings, Journal of Travel Research 43(2): 180-192. http://dx.doi.org/10.1177/0047287504268247

Travkina, I.; Tvaronavičienè, M. 2011. Export competitiveness and domestic productivity facets: case of Lithuania, Journal of Business Economics and Management 12(1): 49-68.

http://dx.doi.org/10.3846/16111699.2011.555360

Valuckaite, A.; Snieska, V. 2007. Export pricing in business-to-business market, Inzinerine Ekonomika - Engineering Economics (4): 103-109.

Wagner, J. M.; Shimshak, D. G. 2007. Stepwise selection of variables in data envelopment analysis: procedures and managerial perspectives, European Journal of Operational Research 180: 57-67. http://dx.doi.org/10.1016/j.ejor.2006.02.048

Walters, P. 1983. Export information sources - a study of their usage and utility, International Marketing Review 1: 34-43. http://dx.doi.org/10.1108/eb008250

Wang, J. J.; Jing, Y. Y.; Zhang, C. F.; Zhang, X. T.; Shi, G. H. 2008. Integrated evaluation of distributed triple-generation systems using improved grey incidence approach, Energy 33(9): 1427-1437. http://dx.doi.org/10.1016/j.energy.2008.04.008

Yan-hui, C.; Liu, S.; Xu, Z.; Zhu, J. 2007. Grey incidence analysis of energy utilization efficiency, in IEEE International Conference on Grey Systems and Intelligent Services, 18-20 November, 2007, Nanjing, Chnia.

Yue, H. 2009. Grey absolute degree of incidence analysis of citation indicators of management academic journals, in IITA'09 Proceedings of the 3rd International Conference on Intelligent Information Technology Application, 21-22 November, 2009, NanChang, China.

Zavadskas, E. K.; Kaklauskas, A.; Trinkūnas, V. 2005. eGovernment and intelligent systems for international trade, in Electronic Government: Workshop and Poster Proceedings of the International EGOV Conference, Schriftenreihe Informatik, Band 15. Linz: Trauner Verlag, 366-373 Zhou, T.; Lin, G.; Li, Y. 2010. Determinants of interest in the acquisition of export skills for Chinese exporters, Journal of Technology Management in China 5(3): 196-212.

http://dx.doi.org/10.1108/17468771011086229

Zhou, C.; Liu, S.; Tang, X. 2005. The Grey Incidence Analysis on the SIC of the ECYR in Jiangsu, in IEEE International Conference on Systems, Man and Cybernetics, vol. 2, 12-14 October, 2005, Waikoloa.

Zia, B. H. 2008. Export incentives, financial constraints, and the (mis) allocation of credit: microlevel evidence from subsidized export loans, Journal of Financial Economics 87(2): 498-527. http://dx.doi.org/10.1016/j.jfineco.2006.12.006 
Seyed Hossein RAZAVI HAJIAGHA. Assistant professor at the Department of Systemic and Productivity Studies at Institute for Trade Studies and Research, Tehran, Iran. He received a PhD in Production and Operation Management in 2012. He is author and co-author of about 10 scientific papers. Research interests include multiple criteria analysis, decision-making theories, data envelopment analysis and industrial problems mathematical modeling.

Edmundas Kazimieras ZAVADSKAS. Prof., the Head of the Department of Construction Technology and Management at Vilnius Gediminas Technical University, Lithuania. PhD in Building Structures (1973). Dr Sc. (1987) in Building Technology and Management. A member of Lithuanian and several foreign Academies of Sciences. Doctore Honoris Causa from Poznan, Saint-Petersburg and Kiev universities. A member of international organizations; a member of steering and programme committees at many international conferences; a member of the editorial boards of several research journals; the author and co-author of more than 400 papers and a number of monographs in Lithuanian, English, German and Russian. Research interests: building technology and management, decision-making theory, automation in design and decision support systems.

Shide Sadat HASHEMI. M.A. in production and operation management, she has worked as a researcher since 2009. Her research interests include operation management, multiple criteria decision making and data envelopment analysis. She is author and co-author of 6 scientific papers. 